\title{
ANALISIS FAKTOR-FAKTOR YANG MEMPENGARUHI KEPUTUSAN NASABAH MENABUNG DI BANK
}

\author{
Venny Adhita Octaviani \\ Fakultas Ilmu Sosial dan Ilmu Politik Universitas Kapuas Sintang \\ Jln. Y.C.Oevang Oeray No.92 Sintang, Kalimantan Barat \\ Email: adhitavenny@gmail.com
}

\begin{abstract}
Abstrak: Penelitian ini bertujuan untuk mengetahui dan menganalisis faktor-faktor yang mempengaruhi keputusan nasabah menabung di Bank Kalbar Cabang Nanga Pinoh. Metode penelitian yang digunakan adalah deskriptif kuantitatif dengan sampel nasabah yang menabung pada Bank Kalbar Cabang Nanga Pinoh yang berjumlah 100 orang responden. Hasil penelitian menunjukkan bahwa yaitu model regresi yang terbentuk dalam penelitian ini yaitu $Y=0,281+0,212$ $\mathrm{X} 1+0,844 \mathrm{X} 2+0,019 \mathrm{X} 3+0,139 \mathrm{X} 4$. Produk berpengaruh signifikan terhadap keputusan nasabah menabung pada Bank Kalbar Cabang Nanga Pinoh, dengan tingkat signifikansi t hitung $<$ dari 0,05 $(0,00<0,05)$. Pelayanan berpengaruh signifikan terhadap keputusan nasabah menabung pada Bank Kalbar Cabang Nanga Pinoh, dengan tingkat signifikansi t hitung $<$ dari $0,05(0,00<0,05)$. Promosi tidak berpengaruh signifikan terhadap keputusan nasabah menabung pada Bank Kalbar Cabang Nanga Pinoh, dengan tingkat signifikansi t hitung $>$ dari $0,05(0,502>0,05)$. Lokasi berpengaruh signifikan terhadap keputusan nasabah menabung pada Bank Kalbar Cabang Nanga Pinoh, dengan tingkat signifikansi t hitung < dari $0,05(0,037<0,05)$. Secara simultan variabel produk $(X 1)$,pelayanan $(\mathrm{X} 2)$, promosi $(\mathrm{X} 3)$ dan lokasi $(\mathrm{X} 4)$ berpengaruh terhadap variabel keputusan menabung $(\mathrm{Y})$ dimana tingkat signifikansi Fhitung $<0,005,(0,00<0,05)$. Hasil uji koefisien determinasi menunjukkan bahwa 95,6\% variabel keputusan menabung (Y) akan dipengaruhi oleh variabel bebasnya, yaitu produk (X1),pelayanan (X2), promosi (X3) dan lokasi (X), sedangkan sisanya 4,4\% variabel keputusan menabung akan dipengaruhi oleh variabel-variabel yang lain yang tidak dibahas dalam penelitian
\end{abstract} ini.

Kata Kunci: Analisis, Keputusan, Nasabah, Menabung

Persaingan dunia bisnis perbankan di Indonesia saat ini semakin gencar yang salah satunya ditandai dengan banyaknya jumlah bank yang beroperasi. Bank-bank tersebut berlomba mencari nasabah agar mau menyimpan uang atau menggunakan fasilitas pinjaman atau kredit yang mereka miliki. Peranan bank sangatlah penting bagi pereknomian suatu negara dalam hal mendukung pembangunan, karena pembangunan ekonomi di suatu negara sangat bergantung kepada dinamika perkembangan dan kontribusi nyata dari sektor perbankan. Pertumbuhan dalam perkembangan bank terutama bank konvensional bisa dilihat dari semakin banyaknya jaringan, aset, banyaknya produk -produk yang ditawarkan dan banyaknya Dana Pihak Ketiga (DPK) yang dihimpun dari masyarakat.Untuk memenangkan persaingan, penting bagi bank untuk mengetahui apa saja yang menjadi kebutuhan dan keinginan calon nasabahnya. Oleh sebab itu, bank harus senantiasa mempelajari dan mengamati bagaimana pola perilaku calon nasabah, agar mereka dapat memberikan kepuasan kepada nasabah atau calon nasabah tersebut.

Bank Pembangunan Daerah Kalimantan Barat didirikan berdasarkan Peraturan Daerah No. 1 Tahun 1963 dengan bentuk hukum Perusahaan Daerah. Ijin usaha dikeluarkan oleh Menteri Urusan Bank Sentral/Gubernur Bank Indonesia dengan Surat Keputusan No. 44/63/Kep/MUBS/ G tanggal 28 November 1963, peresmiannya dilakukan pada tanggal 15 April 1964. Dengan diberlakukannya Undang-Undang No. 7 tahun 1992 tentang Perbankan, Menteri Keuangan Republik Indonesia memberikan ijin usaha Bank Pembangunan Daerah (BPD) sesuai surat No. S841/MK.071/1993 tanggal 18 Agustus 1993. Sementara itu, Bank Kalbar Cabang Nanga Pinoh berdiri pada tanggal 10 November 1969 berdasarkan SK Menteri Keuangan Nomor D.15.6.7.29.

Pada tahun 1999 berdasarkan Perda No. 1 tanggal 2 Februari 1999 terjadi perubahan status hukum BPD Kalbar dari Perusahaan Daerah menjadi Perseroan Terbatas serta perubahan nama menjadi PT. Bank Pembangunan Daerah Kalimantan Barat dengan call name Bank Kalbar melalui Akta Notaris Widiyansyah, SH No. 81 tanggal 23 April 1999 dan telah disahkan oleh Menteri Kehakiman pada tanggal 5 Mei 1999 No. C2-8229 HT.01.01 tahun 1999 dan diumumkan dalam Berita Negara No. 56 tanggal 13 Juli 1999. Tanggal 7 Mei 1999, Bank Kalbar mengikuti Program Rekapitalisasi Perbankan. Pada tanggal 30 Juli 2004, Bank Kalbar menyelesaikan program rekapitulasi, disertai pembelian kembali kepemilikan saham yang dimiliki Pemerintah Pusat oleh Pemerintah Provinsi, Kabupaten dan Kota seKalimantan Barat. 
Dalam operasionalisasinya, Bank Kalbar menyediakan produk simpanan dan pinjaman serta memberikan pelayanan-pelayanan dalam jasa keuangan lainnya. Bank Kalbar menyediakan produk simpanan berupa giro, Tabungan Simpeda, Tabungan Taserna, TabunganKu, Tabungan Bekal, Tabungan Siswa, Tabungan Simpel, Tabungan Profita dan Deposito. Tiap-tiap produk tabungan tersebut memiliki syarat dan ketentuan masingmasing. Di sisi lain, tiap-tiap produk tersebut memiliki beberapa keunggulan dan kelemahan. Adapun dalam mempengaruhi nasabah menabung di Bank Kalbar, ada empat aspek yang sangat di prioritaskan, yaitu: 1). Produk yang ditawarkan 2). Pelayanan yang diberikan yaitu suatu usaha melayani kebutuhan para pelanggan/nasabah. 3). Promosi yaitu suatu cara memperkenalkan, memberitahukan dan mengingatkan kembali manfaat suatu produk agar mendorong konsumen untuk membeli produk yang dipromosikan tersebut. 4). Lokasi yang di dalam dunia perbankan lebih di tekankan pada lokasi kantor dan lokasi ATM di dalam atau di luar bank, hal ini disebabkan agar nasabah mudah menjangkau setiap lokasi bank yang harus memberikan rasa nyaman dan aman kepada seluruh nasabah.

Menurut Kotler dan Armstrong (2008: 337), produk adalah segala sesuatu yang dapat ditawarkan ke pasar untuk mendapatkan perhatian, dibeli, dimiliki, digunakan, atau dikonsumsi yang dapat memuaskan keinginan atau kebutuhan pemakainya. Sedangkan menurut Boyd, et. al. (2000:264) produk dapat didefinisikan sebagai "apa saja yang dapat memenuhi keinginan atau kebutuhan dalam hal penggunaan, konsumsi, atau akuisisi”. Pelayanan menurut Kamus Besar Bahasa Indonesia (KBBI) adalah sebagai suatu usaha untuk membantu menyiapkan atau mengurus apa yang diperlukan orang lain. Sedangkan menurut Moenir (2010:26) pelayanan adalah kegiatan yang dilakukan oleh seseorang atau sekelompok orang dengan landasan faktor materi melalui sistem, prosedur dan metode tertentu dalam rangka usaha memenuhi kepentingan orang lain sesuai dengan haknya.

Menurut Kotler dalam Supranto (2006:228) karakteristik pelayanan atau jasa, Intangible (tidak terwujud); Suatu jasa memiliki sifat tidak berwujud, tidak dapat dirasakan dan dinikmati sebelum dibeli oleh konsumen. Inseparibility (tidak dapat dipisahkan); Pada umumnya jasa yang diproduksi (dihasilkan) dan dirasakan pada waktu bersamaan dan apabila dikehendaki oleh seseorang untuk diserakan kepada pihak lainnya, maka dia akan tetap merupakan bagian dari jasa tersebut. Variability (bervariasi)J; asa senantiasa mengalami perubahan, tergantung dari siapa penyedia jasa, penerima jasa dan kondisi dimana jasa tersebut diberikan. Perishability (tidak tahan lama); Daya tahan suatu jasa tergantung suatu situasi yang diciptakan oleh berbagai faktor. Sedangkan menurut Sampara dalam Sinambela (2011:5) pelayanan adalah suatu kegiatan atau urutan kegiatan yang terjadi dalam interaksi langsung antar seseorang dengan orang lain atau mesin secara fisik, dan menyediakan kepuasan pelanggan.

'Menurut Hasan (2009:10), "promosi adalah fungsi pemasaran yang fokus untuk mengkomunikasikan program-program pemasaran secara persuasive kepada target pelanggan-calon pelanggan (audience) untuk mendorong terciptanya transaksi pertukaran antara perusahaan dan audience". Menurut Kotler dan Armstrong (2014:77), "Promosi adalah aktivitas yang mengkomunikasikan keunggulan produk dan membujuk pelanggan untuk membeli produk itu". Menurut Mullin dan Cummin (2008:36) terdapat 4 (empat) sarana promosi yaitu: Iklan (Advertising); Iklan adalah informasi yang isinya membujuk khalayak banyak atau orang banyak agar tertarik pada suatu barang atau jasa yang ditawarkan. Promosi Penjualan (Sales Promotion); Promosi penjualan adalah rangsangan langsung yang ditujukan kepada konsumen untuk melakukan pembelian. Publisitas (Publicity); Publisitas merupakan salah satu kegiatan dalam bauran pemasaran. Publisitas berperan untuk membantu publikmembuat pilihan yang menguntungkan, karena publisitas sendiri merupakan sebuah kegiatan untuk menceritakan kepada masyarakat luas tentang produk atau jasa yang berkaitan dengan suatu perusahaan atau organisasi. Pemasaran Langsung (Direct Market); Pemasaran langsung adalah suatu proses atau sistem pemasaran dimana orang atau organisasi yang melakukan pemasaran tersebut berkomunikasi langsung dengan target konsumen untuk melakukan penjualan.

Menurut Kasmir (2006:129) Lokasi merupakan tempat melayani konsumen, dapat pula diartikan sebagai tempat untuk memajangkan barang-barang dagangannya. Definisi lokasi adalah tempat perusahaan beroperasi atau tempat perusahaan melakukan kegiatan untuk menghasilkan barang dan jasa yang mementingkan segi ekonominya. Beberapa kriteria yang dapat digunakan untuk menilai suatu lokasi yang strategis menurut Adiwijaya (2010:43) adalah Letak lokasi yang berada atau di sekitar (dekat dengan) pusat aktivitas perdagangan dan perkantoran. Kedekatan lokasi dengan target pasar. Terlihat jelas dari sisi jalan. Akses ke lokasi baik.

Menurut Alma (2011:96), mengemukakan bahwa keputusan pembelian adalah :"Suatu keputusan konsumen yang dipengaruhi oleh ekonomi keuangan, teknologi, politik, budaya, produk, harga, lokasi, promosi, physical evidence, peopledan process, sehingga membentuk suatu sikap pada konsumen untuk mengolah segala informasi dan mengambil kesimpulan berupa responseyang muncul produk apa yang akan 
dibeli”.Sedangkan Menurut Philip Kotler dalam Susanto (2012 : 202) mengemukakan bahwa keputusan pembelian dapat diartikan sebagai suatu keputusan yang diambil oleh seorang calon pembeli menyangkut kepastian akan membeli atau tidak. Proses keputusan pembelian yang spesifik menurut Kotler dan Armstrong (2008:179) terdiri dari Pengenalan masalah, yaitu konsumen menyadari akan adanya kebutuhan. Konsumen menyadari adanya perbedaan antara kondisi sesungguhnya dengan kondisi yang di harapkan. Pencarian informasi, yaitu konsumen ingin mencari lebih banyak konsumen yang mungkin hanya memperbesar perhatian atau melakukan pencarian informasi secara aktif. Evaluasi alternatif, yaitu mempelajari dan mengevaluasi alternatif yang diperoleh melalui pencarian informasi untuk mendapatkan alternatif pilihan terbaik yang akan digunakan untuk melakukan keputusan pembelian. Keputusan membeli, yaitu melakukan keputusan untuk melakukan pembelian yang telah diperoleh dari evaluasi alternatif terhadap merek yang akan dipilih. Perilaku sesudah pembelian, yaitu keadaan dimana sesudah pembelian terhadap suatu produk atau jasa maka konsumen akan mengalami beberapa tingkat kepuasan atau ketidakpuasan.

Teknik analisis data yang digunakan yakni menggunakan analisis linear berganda dengan bantuan program SPSS versi 16. Sebelum dilakukan uji analisis data, peneliti terlebih dahulu melakukan uji validitas dan realibilitas.

\section{METODE PENELITIAN}

Penelitian dilaksanakan pada PT Bank Kalbar Cabang Nanga Pinoh. Jenis penelitian ini berupa deskriptif kuantitatif yaitu penelitian yang mengukur kekuatan hubungan antar dua variabel atau lebih untuk menggambarkan sifat-sifat (karakteristik) dari objek penelitian yang dilakukan melalui pengumpulan dan analisis data.Populasi dalam penelitian ini adalah seluruh nasabah yang menabung pada Bank Kalbar Cabang Nanga Pinoh yang berjumlah 56.716 nasabah. Teknik pengambilan sampel yang akan digunakan oleh peneliti dalam penelitian ini adalah purposive sampling dengan menetapkan kriteria sebagai berikut: 1). Responden adalah nasabah yang menabung pada PT Bank Kalbar Cabang Nanga Pinoh, 2). Responden telah berusia diatas 17 Tahun. Dasar penentuan usia ini disebabkan usia diatas 17 tahun dirasa telah dapat mengambil keputusan terkait menabung pada PT. Bank Kalbar Cabang Nanga Pinoh.

Adapun jumlah sampel dalam penelitian ini dietntukan dengan menggunakan pendapat Solvin (dalam Umar, 2005;146) dengan rumus sebagai berikut: $\mathrm{n}=\frac{N}{1+N e^{2}}$

$$
\begin{aligned}
& \mathrm{n}=\frac{56.716}{1+56.716(0,1)^{2}} \\
& \mathrm{n}=\frac{56.716}{568,16} \\
& \mathrm{n}=99,8 \text { dibulatkan menjadi } 100 \text { responden. }
\end{aligned}
$$

HASIL PENELITIAN DAN

\begin{tabular}{|c|c|c|c|}
\hline Variabel/item & Nilai r Hitung & Nilai r Syarat & Hasil Uji \\
\hline \multicolumn{4}{|l|}{ Produk (X1) } \\
\hline P1 & 0,697 & 0,30 & Valid \\
\hline P2 & 0,559 & 0,30 & Valid \\
\hline P3 & 0,516 & 0,30 & Valid \\
\hline \multicolumn{4}{|l|}{ Pelayanan (X2) } \\
\hline L1 & 0,441 & 0,30 & Valid \\
\hline L2 & 0,514 & 0,30 & Valid \\
\hline L3 & 0,555 & 0,30 & Valid \\
\hline L4 & 0,441 & 0,30 & Valid \\
\hline L5 & 0,581 & 0,30 & Valid \\
\hline \multicolumn{4}{|l|}{ Promosi (X3) } \\
\hline Pro1 & 0,765 & 0,30 & Valid \\
\hline Pro2 & 0,619 & 0,30 & Valid \\
\hline Pro3 & 0,584 & 0,30 & Valid \\
\hline MO3 & 0,638 & 0,30 & Valid \\
\hline MO4 & 0,806 & 0,30 & Valid \\
\hline \multicolumn{4}{|l|}{ Lokasi (X4) } \\
\hline Lo1 & 0,394 & 0,30 & Valid \\
\hline Lo2 & 0,482 & 0,30 & Valid \\
\hline Lo3 & 0,473 & 0,30 & Valid \\
\hline \multicolumn{4}{|c|}{ Keputusan Menabung (Y) } \\
\hline K1 & 0,644 & 0,30 & Valid \\
\hline K2 & 0,341 & 0,30 & Valid \\
\hline K3 & 0,581 & 0,30 & Valid \\
\hline K4 & 0,499 & 0,30 & Valid \\
\hline
\end{tabular}
PEMBAHASAN

Hasil Uji Validitas Dan Reliabilitas

Hasil Pengujian Validitas

Sumber: Data Primer, Diolah, 2020. 
Nilai $r$ hitung masing-masing item pertanyaan/pernyataan pada variabel penelitian lebih besar dari $r$ yang dipersyaratkan. Sehingga dapat disimpulkan bahwa seluruh item pertanyaan dalam instrumen penelitian ini dapat dinyatakan valid dan layak jika digunakan untuk mengukur faktor-faktor yang mempengaruhi keputusan nasabah menabung di Bank Kalbar Cabang Nanga Pinoh.

Hasil Uji Reliabilitas

\begin{tabular}{|l|c|c|c|}
\hline \multicolumn{1}{|c|}{ Variabel } & Cronbach's Alpha & $\begin{array}{c}\text { Cronbach's Alpha } \\
\text { Standar }\end{array}$ & Hasil Uji \\
\hline Produk (X1) & 0,753 & 0,60 & Reliabel \\
\hline Pelayanan (X2) & 0,741 & 0,60 & Reliabel \\
\hline Promosi (X3) & 0,862 & 0,60 & Reliabel \\
\hline Lokasi (X4) & 0,639 & 0,60 & Reliabel \\
\hline Keputusan(Y) & 0,722 & 0,60 & Reliabel \\
\hline
\end{tabular}

Sumber: Data Primer, Diolah, 2020

Seluruh item dalam instrumen penelitian dinyatakan reliabel dan konsisten jika digunakan untuk mengukur faktor-faktor yang mempengaruhi

keputusan nasabah menabung di Bank Kalbar Cabang Nanga Pinoh.

\section{Uji Analisis Linier Regresi Berganda}

Hasil Uji Regresi Linier Berganda Coefficients $^{\text {a }}$

\begin{tabular}{|c|c|c|c|c|c|}
\hline \multirow[b]{2}{*}{ Model } & \multicolumn{2}{|c|}{ Unstandardized Coefficients } & \multirow{2}{*}{$\begin{array}{c}\text { Standardized } \\
\text { Coefficients } \\
\text { Beta }\end{array}$} & \multirow[b]{2}{*}{$\mathbf{t}$} & \multirow[b]{2}{*}{ Sig. } \\
\hline & B & Std. Error & & & \\
\hline $\begin{array}{ll}1 & \text { (Constant) } \\
\end{array}$ & .281 & .382 & & .735 & .464 \\
\hline $\mathrm{X} 1$ & .212 & .040 & 198 & 5.329 & .000 \\
\hline$\times 2$ & .844 & .048 & 1.026 & 17.422 & .000 \\
\hline $\mathrm{x} 3$ & .019 & .028 & .026 & .673 & .502 \\
\hline $\mathrm{x} 4$ & .139 & .066 & .112 & 2.117 & .037 \\
\hline
\end{tabular}

Sumber: Data Primer, Diolah 2020.

berikut:

Tabel 3 tersebut dapat dijelaskan sebagai

1. Berdasarkan hasil pengolahan data pada tabel 3 diperoleh persamaan regresi linier berganda yaitu $Y=0,281+0,212 X 1+0,844 X 2+0,019 X 3$ $+0,139 \mathrm{X} 4$

2. Konstanta (a) $=0,281$ berarti bahwa keputusan nasabah menabung akan konstan sebesar 0,281 satuan jika tidak ada pengaruh dari produk (X1), pelayanan (X2), promosi (X3) dan lokasi (X4)

3. Keputusan nmenabung akan meningkat sebesar 0,212 satuan untuk setiap tambahan satu satuan produk (X1), Jadi apabila produk mengalami peningkatan 1 satuan, maka keputusan menabung akan meningkat sebesar 0,212 satuan dengan asumsi variabel yang lainnya dianggap konstan.
4. Keputusan menabung akan meningkat sebesar 0,844 satuan untuk setiap tambahan satu satuan pelayanan (X2). Jadi apabila pelayanan mengalami peningkatan 1 satuan, maka keputusan menabung akan meningkat sebesar 0,844 satuan dengan asumsi variabel yang lainnya dianggap konstan.

5. Keputusan menabung akan meningkat sebesar 0,019 satuan untuk setiap tambahan satu satuan promosi (X3). Jadi apabila promosi mengalami peningkatan 1 satuan, maka keputusan menabung akan meningkat sebesar 0,019 satuan dengan asumsi variabel yang lainnya dianggap konstan.

6. Keputusan menabung akan meningkat sebesar 0,139 satuan untuk setiap tambahan satu satuan lokasi (X4). Jadi apabila lokasi mengalami peningkatan 1 satuan, maka keputusan menabung akan meningkat sebesar 0,139 satuan dengan asumsi variabel yang lainnya dianggap konstan. 


\section{Pengujian Hipotesis}

Uji t

Uji t digunakan untuk menguji secara parsial masing-masing variabel. Hasil uji t dapat dilihat pada tabel coefficient pada kolom sig (significance).
Jika probabilitas nilai t signifikan $<0,05$ maka dapat dikatakan bahwa terdapat pengaruh antara variabel bebas terhadap variabel terikat.

Nilai Koefisien t Variabel Penelitian

\begin{tabular}{|l|c|c|}
\hline \multicolumn{1}{|c|}{ Variabel } & $\mathrm{t}$ & Sig. \\
\hline (Constant) & 0,735 & 0,464 \\
\hline Produk (X1) & 5,329 & 0,000 \\
\hline Pelayanan (X2) & 17,422 & 0,000 \\
\hline Promosi (X3) & 0,673 & 0,502 \\
\hline Lokasi (X4) & 2,117 & 0,037 \\
\hline
\end{tabular}

Dependent Variable: Keputusan Menabung (Y)

Sumber: data primer, diolah 2020.

Berdasarkan hasil uji tersebut diuraikan sebagai berikut:

1.Besarnya koefisien thitung untuk variabel produk adalah 0,735 dengan tingkat signifikansi 0,000 yang lebih kecil dari 0,05 , sehingga dapat disimpulkan bahwa $\mathrm{HO}$ ditolak dan Ha diterima, sehingga hipotesis pertama dalam penelitian ini produk berpengaruh signifikan terhadap keputusan nasabah menabung pada Bank Kalbar Cabang Nanga Pinoh.

2. Besarnya koefisien $t$ hitung untuk variabel pelayanan adalah 5,329 dengan tingkat signifikansi 0,000 yang lebih kurang dari 0,05, sehingga dapat disimpulkan bahwa hipotesis kedua dalam penelitian ini pelayanan berpengaruh signifikan terhadap keputusan nasabah menabung pada Bank Kalbar Cabang Nanga Pinoh.

3.Besarnya koefisien $t$ hitung untuk variabel promosi adalah 0,673 dengan tingkat signifikansi 0,502 yang lebih besar dari 0,05 , sehingga dapat disimpulkan bahwa hipotesis ketiga dalam penelitian ini promosi tidak berpengaruh signifikan terhadap keputusan nasabah menabung pada Bank Kalbar Cabang Nanga Pinoh.

4.Besarnya koefisien thitung untuk variabel lokasi adalah 2,117 dengan tingkat signifikansi 0,037 yang lebih kurang dari 0,05 , sehingga dapat disimpulkan bahwa hipotesis keempat dalam penelitian ini lokasi berpengaruh signifikan terhadap keputusan nasabah menabung pada Bank Kalbar Cabang Nanga Pinoh.

Hasil uji simultan atau uji F pada penelitian ini adalah untuk mengetahui apakah semua variabel bebas yang dimasukkan ke dalam model penelitian mempunyai pengaruh secara bersama-sama terhadap variabel terikat. Hasil uji F dapat dilihat pada tabel Anova output dari program SPSS. Selanjutnya hasil uji $\mathrm{F}$ tersebut dibandingkan dengan $\mathrm{F}$ tabel. Jika $\mathrm{F}$ hitung $>$ dari $\mathrm{F}$ tabel maka hipotesis diterima dan sebaliknya jika F hitung < dari F Tabel maka hipotesis ditolak.

Hasil Uji F (Simultan)

\begin{tabular}{|l|r|r|r|r|r|}
\hline Model & Sum of Squares & df & Mean Square & \multicolumn{1}{|c|}{ F } & Sig. \\
\hline 1 Regression & 699.145 & 4 & 174.786 & 514.962 & $.000^{\text {a }}$ \\
Residual & 32.245 & 95 & .339 & & \\
\multicolumn{1}{|c|}{ Total } & 731.390 & 99 & & & \\
\hline
\end{tabular}

a. Predictors: (Constant), X4, X1, X3, X2

b. Dependent Variable: Y

Sumber: data primer, diolah tahun 2020.

Sig. pada tabel ANOVA tersebut adalah 0,000 yang lebih kecil dari 0,05 maka model analisis regresi adalah signifikan. Hal ini berarti Ha diterima sehingga dapat disimpulkan bahwa. Hal ini berarti
H0 ditolak dan Ha diterima sehingga dapat disimpulkan bahwa variabel produk (X1),pelayanan (X2), promosi (X3) dan lokasi (X4) berpengaruh secara simultan terhadap variabel keputusan menabung (Y). 


\section{Koefisien Determinasi}

Koefisien determinasi digunakan untuk mengetahui besar kontribusi variabel produk (X1),pelayanan (X2), promosi (X3) dan lokasi (X4) berpengaruh secara simultan terhadap variabel keputusan menabung (Y). Langkah yang dapat digunakan yaitu dengan melihat nilai $R$ Square pada tabel model summary sebagai berikut:

Tabel 6 Koefesien Determinasi

Model Summary

\begin{tabular}{|l|c|r|r|r|}
\hline Model & \multicolumn{1}{|c|}{$\mathrm{R}$} & \multicolumn{1}{|c|}{ R Square } & Adjusted R Square & Std. Error of the Estimate \\
\hline 1 & $.978^{2}$ & .956 & .954 & .583 \\
\hline
\end{tabular}

a. Predictors: (Constant), X4, X1, X3, X2

Sumber: Data primer, diolan tanun $2 U 2 U$.

Koefisien determinasi digunakan untuk menghitung besarnya pengaruh atau kontribusi variabel bebas terhadap variabel terikat. Dari analisis pada Tabel 6 diperoleh hasil $R$ Square (koefisien determinasi) sebesar 0,956 yang menunjukkan bahwa 95,6\% variabel keputusan menabung (Y) akan dipengaruhi oleh variabel bebasnya, yaitu produk (X1), pelayanan (X2), promosi (X3) dan lokasi (X), sedangkan sisanya 4,4\% variabel keputusan menabung akan dipengaruhi oleh variabel-variabel yang lain yang tidak dibahas dalam penelitian ini.

\section{KESIMPULAN DAN SARAN}

Produk berpengaruh signifikan terhadap keputusan menabung nasabah pada Bank Kalbar Cabang Nanga Pinoh. Hal ini menunjukkan bahwa atribut yang ditampilkan didalam produk tabungan menjadi salah satu faktor yang mempengaruhi seorang nasabah menabung atau tidak. Pelayanan berpengaruh signifikan terhadap keputusan menabung. Pelayanan yang prima akan menimbulkan kepuasan tersendiri bagi pelanggan dalam hal ini adalah nasabah. semakin baik pelayanan yang diberikan oleh bank maka akan mempengaruhi ke'putusan nasabah dalam menabung. Promosi tidak berpengaruh signifikan terhadap keputusan menabung nasabah pada Bank Kalbar Cabang Nanga Pinoh. Hal ini dikarenakan promosi yang dilakukan oleh bank Kalbar khususnya tidak terlalu banyak dan tidak menjangkau banyak audiens khususnya di Nanga Pinoh. Lokasi berpengaruh signifikan terhadap keputusan menabung. Artinya semakin terjangkau suatu lokasi akan memberikan kemudahan terutama bagi nasabah untuk menyimpan uangnya. Diharapkan agar Bank Kalbar senantiasa menjaga kualitas produk dan selalu berinovasi dalam penyediaan produk khususnya produk tabungan agar semakin banyak masyarakat tertarik untuk menabung di Bank Kalbar. Diharapkan agar Bank Kalbar senantiasa memberikan pelayanan prima dan terbaik untuk menjaga kepuasan nasabah. Diharapkan agar bank Kalbar terus melakukan promosi yang dapat dilihat oleh audiens. Sehingga masyarakat mengenal Bank Kalbar, tertarik dan akhirnya memutuskan untuk menyimpan uang mereka di Bank Kalbar. Diharapkan agar Bank Kalbar dapat membuka unit-unit cabang di berbagai lokasi, sehingga dapat memudahkan nasabah dalam bertransaksi dan keputusan menabungpun semakin meningkat.

\section{DAFTAR PUSTAKA}

Alma, Buchari. 2011. Manajemen Pemasaran dan Pemasaran Jasa, Cetakan Kesembilan. Bandung: Alfabeth.

Hasan, Ali. 2009. Marketing, Yogyakarta : MedPress (Anggota IKAPI)

Kasmir. 2001.Manajemen Perbankan. Jakarta: Raja Grafindo Persada.

Kotler, Philip; Armstrong, Garry. 2008. Prinsipprinsip Pemasaran,Jilid 1.Jakarta: Erlangga.

Kotler, Philip; Armstrong, Gary. 2014. Prinsipprinsip Manajemen. Edisi 14, Jilid1. Jakarta: Erlangga.

Moenir, A.S. 2010. Manajemen Pelayanan Umum Di Indonesia. Jakarta: Bumi Aksara.

Mullin, Roddy and Cummins, Julian. 2008. Sales Promotion. Jakarta: PPM.

Sinambela, Lijan Poltak. Dkk. 2011 .Reformasi Pelayanan Publik. Jakarta:BumiAksara.

Supranto. 2006. Mengukur Tingkat Kepuasan Pelanggan atau Konsumen. Jakarta: Rineka Cipta. 